July 2017

\title{
Teaching Intercultural Communicative Competence: The Perspective of Foreign Language Graduate Student Instructors
}

Carla Ghanem

Arizona State University at the Tempe Campus, carla.ghanem@asu.edu

Follow this and additional works at: https://digitalcommons.georgiasouthern.edu/ij-sotl

\section{Recommended Citation}

Ghanem, Carla (2017) "Teaching Intercultural Communicative Competence: The Perspective of Foreign Language Graduate Student Instructors," International Journal for the Scholarship of Teaching and Learning: Vol. 11: No. 2, Article 9.

Available at: https://doi.org/10.20429/ijsotl.2017.110209 


\title{
Teaching Intercultural Communicative Competence: The Perspective of Foreign Language Graduate Student Instructors
}

\author{
Abstract \\ Cultural awareness and intercultural competence (IC) of students in foreign language (FL) instruction \\ have been widely examined (e.g. Byram, 1997; Belz, 2002). The importance of the FL teacher in aiding \\ students' IC development is less extensively researched, however. Author (2014), Kohler (2015), Sercu et \\ al. (2005) and Sercu (2006) are a few exceptions. The purpose of this study is to shed light on graduate \\ student instructors' (GSIs) perspective of understanding IC and its incorporation into FL courses. Eight \\ GSIs of German at a large US university participated in this qualitative study, which addresses the \\ struggles that these instructors encounter when attempting to understand and teach IC. Findings show \\ that the GSIs do not fully comprehend the term of IC and hence have difficulty including IC in the \\ classroom. This has implications for teacher training and professional development.
}

\section{Keywords}

Intercultural communication; culture teaching; foreign language education; graduate student instructors; intercultural teaching practices; teacher education

\section{Creative Commons License}

c) (i) $\Theta$

This work is licensed under a Creative Commons Attribution-Noncommercial-No Derivative Works 4.0 License. 


\title{
Teaching Intercultural Communicative Competence: The Perspective of Foreign Language Graduate Student Instructors
}

\author{
Carla Ghanem' \\ ISchool of International Letters and Cultures, Arizona State University, Tempe, AZ 85287, USA
}

(Received 2 September 2016; Accepted 6 February 2017)

\begin{abstract}
Cultural awareness and intercultural competence (IC) of students in foreign language (FL) instruction have been widely examined (e.g. Byram, 1997; Belz, 2002). The importance of the FL teacher in aiding students' IC development is less extensively researched, however. Author (20I4), Kohler (2015), Sercu et al. (2005) and Sercu (2006) are a few exceptions. The purpose of this study is to shed light on graduate student instructors' (GSIs) perspective of understanding IC and its incorporation into FL courses. Eight GSIs of German at a large US university participated in this qualitative study, which addresses the struggles that these instructors encounter when attempting to understand and teach IC. Findings show that the GSIs do not fully comprehend the term of IC and hence have difficulty including IC in the classroom. This has implications for teacher training and professional development.
\end{abstract}

\section{INTRODUCTION}

In the American education system, the development of students into global citizens has become essential. In foreign language (FL) education, many organizations and scholars have responded to this need. The American Council on the Teaching of Foreign Languages (ACTFL) and the Modern Language Association's (MLA) ad hoc committee have developed standards and statements that address this aspect of language learning. ACTFL underscores the importance of culture in Standards 2.1 and 2.2, defining culture in the form of products, practices, and perspectives (National Standards, 1999). The MLA ad hoc committee emphasizes that FL majors should develop into "educated speakers who have deep translingual and transcultural competence" (p. 3), which "places value on the ability to operate between languages" (pp. 3-4). This competence allows students to interact with speakers from other cultures and "reflect on the world and themselves through the lens of another language and culture" (MLA, 2007, p. 4). In the European context, Byram (1997) advocates for extending the interaction from a simple exchange of information to "understand[ing] and relat[ing] to people from other countries" (p. 5). Many scholars have investigated the move away from communicative language learning to intercultural communicative competence (ICC) or intercultural competence (IC) in FL education (Aguilar, 2007; Byram, 1997; Deardorff, 2009; Liddicoat, 2002 among others). Although learners' development of IC have been examined (e.g. Belz, 2002), fewer investigations on teachers' development of IC, their comprehension of it, and their education in teaching IC to their students exist. The few reports concentrate on K-12 FL teachers (e.g. Kohler, 2015; Sercu et al., 2005). This study attempts to remediate this lacuna by examining graduate student instructors (GSIs) of German in a post-secondary context and their perception of understanding culture and IC and how they teach it (if they do at all).

\section{LITERATURE REVIEW}

Culture awareness and ICC/IC has become an integral part of the FL classroom. Many scholars and educators remind us, language instructors that language and culture are to be seen as one entity (e.g. Agar, 1994; Kramsch, 2000). Instead of considering language and culture as two separate units, Kramsch (2000) accentuates that culture is "the very core of language teaching" and should aid language proficiency (p. 8). Studies by Chavez $(2002,2005)$ and Yang (2012), among others, on students' beliefs and perspective of language and culture in the FL classroom illustrate various results. Yang's (2012) study on 35 students found that the learners chose a FL for different reasons. Motivation, textbooks, technology, instruction, and assessment played a role for the students. Students motivated due to being heritage learners tended to want to learn about the language, but also the culture to be able to carry out traditions. Chavez (2005) conducted a 33-item survey with 206 students from first through third-year German at a large US university. Her findings illustrated that learners did not equate their definition of culture to what they might encounter in a FL class and particular aspects of culture seemed to have been labeled for majors of the subject only. In the literature on culture in the FL field, a distinction is commonly made between high culture, also referred to as "C" (capital or big C), which includes architecture, art, history, literature, and music, and "c" (little c) which refers to everyday life, behavior, traditions, and the perspectives of the people in the culture of study. In FL education, " $C$ " seemed to have been traditionally preferred over " $\mathrm{c}$ ", however, a shift from " $C$ " to " $\mathrm{c}$ " has occurred with the influences from fields such as Anthropology and Sociology (Hall, 1990). Byram (1986) calls for the inclusion of all features within culture, including " $C$ " and " $c$ ". These definitions of culture and what culture entails supply the content that can be included in instruction, which tends to be very factual and not necessarily very interpretive, or so they seem too many beginning instructors. The Standards for Foreign Language Learning in the 2 Ist $^{\text {st }}$ Century (National Standards, 1999) discuss culture in terms of products, practices, and perspectives (three P's). Two of these three strands represent facts, however, the third strand (perspectives) allows for interpretive expansion. Going beyond the facts and interpreting cultural interaction is what IC tends to emphasize. Many definitions exist for IC; in Byram's (1997) terms, IC is the willingness to consider and respect other beliefs and behaviors "and to analyse them from the viewpoint of the others with whom one is engaging" (p. 34). Liddicoat et al. (2003) state "Intercultural language learning involves developing with learners and understanding of their own language(s) and culture(s) in relation to an additional language and culture." (p. 46). The authors go further by maintaining, "It [intercultural language learning] is a dialogue that allows for reaching a common ground for negotiation to take place, and where variable points of view are recognised, mediated, and accepted" (p. 46). Learning and teaching FLs automatically include IC, yet how the "learning" and "teaching" of IC occurs and how it is mediated in the FL classroom is a question that requires more attention.

Although much research on IC development and general cultural awareness of learners has been done (e.g. Abrams, 2002; Belz, 2002, 2005; Ware, 2005), research on teachers and their teaching of IC has been rather scarce (Doğançay-Aktuna, 2005; Byram \& Kramsch, 2008; Kohler, 2015; Sercu, 2006; Sercu et al., 2005). Of this research, only few studies have been conducted on FL teachers other than English (FLOTE). In preparing teachers of Teaching English as a Second Language (TESOL) to be aware of students' sociocultural backgrounds to make more informed decisions, Doğançay-Aktuna (2005) illustrates how the field of IC can aid these instructors. This study employs IC in the training of future TESOL teachers; however, it does not specifically investigate the actual teaching of IC. This kind of training is vital and a good starting point for FL teacher educators, yet the position FL teachers in the United States find themselves in differs from TESOL teachers. Considering teachers in general, Cushner and Mahon (2009) also discuss IC in teacher education. Their main concern lies on the 
teachers' own IC and just as Doğançay-Aktuna (2005), on how teachers manage classrooms with students from different cultural backgrounds. To include IC in FL classrooms, we need to look at whether or not our FL teachers are interculturally competent. The questions of how and whether FL teachers, especially GSIs, teach IC still need to be investigated.

In 2005, Sercu and her colleagues conducted a study on $424 \mathrm{FL}$ $\mathrm{K}-12$ teachers from seven different countries to find out whether these teachers were willing to teach IC. In line with this research, Sercu (2006) assessed whether these same teachers fulfilled the "foreign language and intercultural competence teacher" requirement (p. 56). Both studies revealed teachers' willingness to incorporate IC; however, teachers also felt that their training did not include teaching IC. Additionally, the participants reported that the curriculum did not allow for the inclusion of IC (see also, e.g., Omaggio-Hadley, 200I). Interestingly, 79\% of Sercu's (2006) participants were English as a Foreign Language (EFL) teachers; only $18 \%$ were $\mathrm{FL}$ teachers $(9 \%$ in German, $7 \%$ in French, and $2 \%$ in Spanish). These numbers illustrate the lack of research on FLOTE. While the study demonstrates the importance of including IC in FL classrooms, actual descriptions of and specific approaches for instructors are lacking. Kohler (2015) conducts a case study with three FLOTEs of Indonesian in secondary school in Australia. Using case study methodology and participatory action research, Kohler (20I5) investigated how teachers mediate IC in their classrooms. Her findings underline the discrepancy between theoretical understandings and teaching practices. A report by Author (2014) discusses FL GSls of German and their understanding of culture and IC and its role in the classroom. The study's findings illustrate the uncertainties that the participants had with the concept of culture and IC. Additionally, these instructors felt a lack of training of how to include culture or even IC in their instruction. Author implies that workshops and continuous training incorporating approaches to teaching IC are lacking and necessary.

The majority of FL lower-division courses across US universities are taught by GSIs. General training for FLOTEs who are GSIs includes a few days (anything from 3-5 days depending on the programs) of preparation to teaching before their first semester starts and a teaching methodology course in their first semester. Since most GSIs are first time teachers, the general training and the course concentrate heavily on basic teaching practices, such as lesson planning, setting and reaching objectives, following standards, creating activities that reflect objectives and outcomes, etc. During this training, GSls are exposed to culture teaching through the ACTFL standards, which discuss culture as the three P's. Other approaches to teaching culture might be discussed and promoted; IC might not have been touched upon at this point. Yet, these GSls are expected to teach towards IC. This group of teachers has not yet been given as much research attention as $\mathrm{K}-\mathrm{I} 2$ teachers. The main purpose of this study is to fill some of that void by examining GSIs, in this case GSIs of German, and their perception of understanding and experiencing teaching IC, in order to see whether these instructors share similar perceived experiences with $\mathrm{K}-\mathrm{I} 2$ teachers and what might be needed to improve the teaching of $\mathrm{IC}$ in $\mathrm{FL}$ classrooms.

\section{METHOD}

\section{Participants}

The participants in this report are eight GSls of German at a large university in the southwestern United States, teaching various German lower-division communicative language courses. Background information on the eight participants comes from the first questionnaire. All subjects were graduate students who held teaching assistantships. Linda, Justin, Paul, and Matthew identified themselves as nonnative speakers (NNSs) of German and Ingrid, Vanessa, Franc, and Joseph identified as native speakers (NSs). At the time of the study, Linda and Justin taught first-semester German,
Ingrid, Paul and Vanessa taught second-semester German, Franc instructed fourth-semester German, and Joseph taught an accelerated second-year German course. Six of the participants have been teaching German at the lower-division level for at least four years; two were in their first or second year of teaching when the study was conducted. All NNS instructors have lived in a Germanspeaking country for at least three months and up to a year. The NSs have lived in the US between two and seventeen years. For an overview of the participants see Table I.

\begin{tabular}{|c|c|c|c|c|}
\hline Participants & Language & Gender & Age & $\begin{array}{l}\text { German } \\
\text { Course }\end{array}$ \\
\hline Linda & $\begin{array}{l}\text { NNS of } \\
\text { German }\end{array}$ & female & $\begin{array}{l}18- \\
25\end{array}$ & $\begin{array}{l}\text { first } \\
\text { semester }\end{array}$ \\
\hline Justin & $\begin{array}{l}\text { NNS of } \\
\text { German }\end{array}$ & male & $\begin{array}{l}26- \\
33\end{array}$ & $\begin{array}{l}\text { first } \\
\text { semester }\end{array}$ \\
\hline Paul & $\begin{array}{l}\text { NNS of } \\
\text { German }\end{array}$ & male & $\begin{array}{l}26- \\
33\end{array}$ & $\begin{array}{l}\text { Second } \\
\text { semester }\end{array}$ \\
\hline Matthew & $\begin{array}{l}\text { NNS of } \\
\text { German }\end{array}$ & male & $\begin{array}{l}26- \\
33\end{array}$ & $\begin{array}{l}\text { Third } \\
\text { semester }\end{array}$ \\
\hline Ingrid & $\begin{array}{l}\text { NS } \\
\text { German }\end{array}$ & female & $\begin{array}{l}18- \\
25\end{array}$ & $\begin{array}{l}\text { Second } \\
\text { semester }\end{array}$ \\
\hline Vanessa & $\begin{array}{l}\text { NS } \\
\text { German }\end{array}$ & female & $\begin{array}{l}26- \\
33\end{array}$ & $\begin{array}{l}\text { Second } \\
\text { semester }\end{array}$ \\
\hline Franc & $\begin{array}{l}\text { NS of } \\
\text { German }\end{array}$ & male & $\begin{array}{l}34- \\
40\end{array}$ & $\begin{array}{l}\text { fourth } \\
\text { semester }\end{array}$ \\
\hline Joseph & $\begin{array}{l}\text { NS } \\
\text { German }\end{array}$ & male & $\begin{array}{l}34- \\
40\end{array}$ & $\begin{array}{l}\text { second-year } \\
\text { accelerated }\end{array}$ \\
\hline
\end{tabular}

\section{Data collection tools}

The subjects completed three questionnaires, wrote three selfreflective journal entries, and participated in a focus-group interview and an individual semi-guided interview. Furthermore, the researcher observed each participant's classroom practices three times. Having a combination of tools serves as triangulation and rich data for analysis.

The first questionnaire contained three sections: I) personal demographic information, 2) classroom teaching experience and 3) classroom culture teaching. The second and third questionnaires included only the last two sections. All sections encompassed multiple-choice and open-ended items. The purpose of using similar questionnaires throughout the study was to see whether instructors changed their teaching practices in regards to culture and/or IC while being engaged with the topic.

To examine GSIs' understanding and attitude towards IC and the teaching thereof, the subjects wrote three self-reflective journal entries - one at the beginning, one midway through, and one at the end of the semester. Reflective journal entries serve to receive a deeper insight to the participants as Boud, Keogh, and Walker (1985) point out, "[r]eflection is a form of response...to experience...[and] consists of the total response of a person to a situation or event: what he or she thinks, feels, does and concludes at the time and immediately after" (p. 18). The journal entries were guided by open-ended questions pertaining to teaching and IC.

Throughout the semester, three classroom observations for each participant were conducted (one at the beginning, one midway through, and one at the end of the semester). Detailed field notes were taken of participants' practices in regards to teaching culture and/or IC. The researcher used these observations mainly to observe whether the class time incorporated any teaching in regards to culture or IC and how culture and/or IC were presented.

At the end of the semester, the focus-group interview, which was videotaped, and the individual semi-guided interviews, which were audiotaped, assisted in clarifying and elaborating on topics and 
concerns that were raised in the questionnaires and self-reflective journal entries. These types of interviews allow the participants to reflect and explain their responses and their thoughts on teaching culture.

\section{Data analysis procedures}

The data was analyzed qualitatively through emergent theme analysis (Merriam, 2009) and grounded theory (Glaser, 1992) by discovering themes and categories that allowed the deep examination of how participants discussed teaching culture and/or IC.

\section{Research Questions}

This study was guided by the following questions: I) what is the nature of GSIs' understanding of culture and intercultural competence? and 2) How do GSls include culture and/or intercultural competence in their own instruction?

\section{FINDINGS AND DISCUSSION}

What is culture?

Participants of this study indicated the importance of culture as well as the time they dedicated to culture in their classrooms on the questionnaires. In all three questionnaires, all subjects agreed that teaching culture is very important. Reporting on the time they dedicated to teaching language and culture in their classroom, their responses differed from questionnaire one through three. Figure I and Table 2 illustrate the item on the questionnaires and the instructors' ratings, respectively. All questions on the surveys were adapted from Sercu et al. (2005):

Figure I. Questionnaire item on time of "culture teaching"

3. How much time do you dedicate to teaching language and teaching culture?

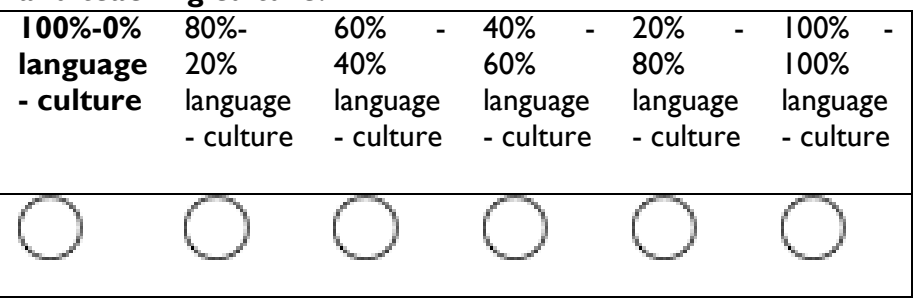

Table 2. Time dedicated to teaching language and culture

respectively

\begin{tabular}{|c|c|c|c|c|c|c|}
\hline \multicolumn{2}{|c|}{ Questionnaire } & \multicolumn{5}{|c|}{$\begin{array}{c}\text { Rating in \% } \\
\text { Language-culture }\end{array}$} \\
\hline & $\begin{array}{l}100-0 \\
\text { language } \\
\text { - culture }\end{array}$ & $\begin{array}{c}80-20 \\
\text { language } \\
\text { - culture }\end{array}$ & $\begin{array}{c}60-40 \\
\text { language } \\
\text { - culture }\end{array}$ & $\begin{array}{c}40-60 \\
\text { language } \\
- \text { culture }\end{array}$ & $\begin{array}{c}20-80 \\
\text { language } \\
\text { - culture }\end{array}$ & $\begin{array}{l}100-100 \\
\text { language } \\
\text { - culture }\end{array}$ \\
\hline I & 0 & $T$ & 4 & $T$ & 0 & 2 \\
\hline II & 0 & 2 & 3 & $\mathrm{I}$ & 0 & 2 \\
\hline $\begin{array}{l}\text { II } \\
\text { I }\end{array}$ & 0 & $\mathrm{I}$ & 4 & 0 & $T$ & 2 \\
\hline
\end{tabular}

Two participants, Ingrid and Vanessa, claim to teach language and culture integrally interspersed, which is an ideal situation and is advocated by scholars (e.g. Agar, 1994; Kramsch, 1998). Teaching language as culture (100\% language- $100 \%$ culture) is not very easy, however, both participants' perception of their dedicated time in the classroom reflects 1005 language- $100 \%$ culture. In the classroom observations of the two above-mentioned GSIs, it became clear that they both try to teach language and culture as one entity, yet their practices reflected either a factual, on the side mentioning of culture or it was missing completely. Half of the GSls tended to return a $60 \%$ language- $40 \%$ culture rating, realizing that the linguistic competence portion of language is what they most likely concentrate on due to their training and their belief of what language is.

Another item on the questionnaires asked participants to rank definitions of culture teaching on a scale from I-5 according to importance. Instructors seemed to have more difficulty completing this task and commented that provided definitions were all equally important. Figure 2 provides the item on all three questionnaires.

The difficulty defining culture and IC aligns with previous research (e.g., Sercu et al., 2005). Most GSls opted for the fourth definition ("Encourage an open-mind and a positive attitude towards foreign languages and cultures") on the first questionnaire; however, other definitions were ranked very closely to the fourth. By midsemester, on the second questionnaire, GSls ranked definition four as the most important again, but not many other classifications followed as closely as they did on the first questionnaire. This result might have occurred due to the constant, continuous, and conscious interaction with culture and IC that GSIs encountered throughout the semester by the study, which might have allowed the participants to realize what teaching culture meant to them. Comparing responses to this item from the first two questionnaires with the last one, a change to another concept appears and all the other definitions were ranked similarly. Participants ranked "Handling intercultural situations" as their number one definition. This new ranking at the end of the semester might have been due to the constant engagement with intercultural and cultural terms and ideas that the participants completed for this study, which illustrates that teachers need the constant and continuous interaction and engagement with pedagogical topics such as culture and intercultural learning. The subjects' uncertainty in defining the term culture and the shift from one concept to another demonstrates the complexity and difficulty of culture. Since the participants struggled with defining the term, it becomes apparent that their understanding of what or how culture should be taught might be unclear. To gain a deeper insight on the GSls' perception of teaching culture and what it entails in the classroom, the participants discussed various ideas and their understanding in the focus-group interview. An important moment occurred when the GSls questioned what culture really is:

Justin: I don't necessarily think that the culture would be the only pragmatics position of that, it would be limited to that, but I think culture is already part of the language to a certain extent. [...]

Justin: So, teaching language and culture would also encompass being able to use language to engage within a culture?

Everybody: Right!

[...]

Justin: The transition is from linguistic fluency so to speak to a more cultural fluency.

Franc: Oh, but they go hand-in-hand. I mean you, in order to understand language, you need to understand the culture and you understand the cultures through the language.

[...]

Linda: Doesn't it depend on how you define culture? Because it's such a broad topic...

(Focus group interview) [emphasis added]

This excerpt underscores the difficulty of defining culture and therefore having to decide what to teach in the classroom. Having the opportunity to discuss this phenomenon with each other, the participants attempt to make sense of the complexity that culture brings to their work. The exchange of information and ideas led the GSls to grasp the concept and the matter better by realizing, as Linda mentions at the end of the excerpt, that defining the term 
might determine the decision of how to teach it and what to include. Another insight that the participants gained from this interaction is the fact that language and culture are inseparable, which is supported by many researchers (e.g., Agar, 1994; Byram \& Kramsch, 2008). The subjects used their understanding of culture as language through culture, following Byram and Kramsch's (2008) concept of "language as culture" (p. 15), however, it seems as if they are still struggling in turning this theory into practice. Additionally, deciding what to teach from this very broad and loaded "subject" seems to be a big problem.

Another aspect that emerged from the participants' data while attempting to define culture is the distinction between " $\mathrm{C}$ " and " $\mathrm{c}$ ". Participants of this study differed in their opinion on which of the two to teach. Linda is one of the subjects who believes that emphasizing " $c$ " seems more important and interesting to her students. In the interview, she states "It's more the day-to-day things, because I think the students are more interested in like differences and ways of life" (emphasis added). Justin agrees with Linda in deeming that daily life aspects are to be part of culture teaching as he explains in the interview that "it's teaching some aspects of every day life, that might be integrated with the vocabulary that you might be teaching, for example, shopping, something like that." (emphasis added). Nonetheless, Justin elaborates further that the daily life is one aspect of teaching, "but there's also aspects of history that are, uhm, can comment on with every day life, uhm that are also important to know." (emphasis added). In the individual interviews with Paul and Vanessa, both agree with Justin:

I think the high culture has its place; it's good to talk about Beethoven. [...] uhm, but I think it is also important to get sort of the everyday life and pop culture, too. (Paul/Interview) [emphasis added].

It's the small things, like just saying "hello" and "goodbye", as I just said; it's music, it's the pop culture, but it's also, like what they were saying small c and big c. (Vanessa/lnterview) [emphasis added]

As can be seen in the participants' explanations of what culture teaching might encompass, the importance of everyday culture combined with "high" culture seems to be the key. How to achieve this balance and how to move towards IC appears to be still unclear for these instructors, and research has not yet offered specific practical guidance. As in other studies, such as Kohler (2015) and Sercu et al. (2005), this study illustrates that instructors at least recognize the significance of culture teaching and have started creating some teaching practices to incorporate culture.

\section{When and how is culture taught?}

Culture teaching, according to the participants, seems to depend partially on the curriculum and level:

It really depends on the course [...] this is what we need to cover, how we do that, is up to us. (Paul/Interview) [emphasis added]

Depending on the class, we teach more or less culture. $2^{\text {nd }}$ year is much more culture than Ist year. (Franc/Questionnaire I) [emphasis added]

I think that the higher the level you probably more get into just culture.

(Linda/Interview) [emphasis added]

I think it depends on what level they're [students] in, you know, $[\ldots]$ then in $3 \mid 2 \mathrm{~K}$ and $\mathrm{L}$ [third $(3 \mid 2 \mathrm{~K})$ and fourth ( $3 \mid 2 L)$ semester German course] we get kind of to these more vague historical, cultural topics.

(Matthew/Interview) [emphasis added]

Franc, Linda, and Matthew strongly believe that higher-level courses incorporate more culture teaching than lower-level courses. Paul also agrees that it depends on the course one is teaching, but also goes further by showing concerns with the "need to cover" certain topics, which is usually dictated by the curriculum. The participants' belief in a correlation of teaching culture to level or curriculum aligns with Sercu et al. (2005) findings on their teachers, who claim that the curriculum does not include time for culture. Although the GSIs in this study claim to have an understanding of language and culture as an entity, they still suppose that whether or not they are teaching culture is not dependent on them, but on other external factors, such as the curriculum or course. Despite the participants' feeling that incorporating culture depends on the level they teach, some claim a marked preference for teaching culture in their journals.

I feel comfortable teaching culture because I derive great satisfaction from explaining about my own culture and background to (in the best of all scenarios) curious listeners.

(Joseph/Self-reflective Journal I) [emphasis added]

I personally feel most comfortable teaching culture, maybe because that is my focus in my own studies and research, I am not sure, but I feel like when I teach culture, I [am] more successful in motivating and engaging my students than when I teach grammar.

(Ingrid/Self-reflective Journal I) [emphasis added]

Teaching culture, for example, gives me the opportunity to show my students aspects of a culture that are not necessarily included in the textbook and differ from place to place. This fluidity of culture and communication is the more satisfying aspect of teaching a foreign language. (Franc/Self-reflective Journal I) [emphasis added]

While the instructors feel they teach culture and like to emphasize it to either motivate students (as in Ingrid's case) or receive "great satisfaction" (as in Joseph's case), or see it as "more satisfying aspect of teaching" (as in Franc's case), having to describe what they do seemed problematic. This raises the question of their self-perception and whether they really are or what they think they are teaching in their classrooms. To investigate further, participants were asked in the interview "how do you teach culture?" Their responses varied. Some looked at culture teaching as historical and factual; others saw culture teaching in terms of using media, such as music; and some had a very difficult time responding to this question:

Yeah, I tend to be historical, quite historical. I tend to historicize culture. When I look at myself sort of while being in the classroom, it also have to do with the fact that we teach 20th century basically, which is of course full of turmoil and everything; so but I think, what I do is, I organize my cultural units around specific historical dates. (Joseph/Interview) [emphasis added]

Yeah, it's a good question. I think I probably, because of time and because of ease in a way and because it is the more interesting thing, I think I do, do a lot of factual cultural teaching... so the way everything is structured, in the way I think we are 
trained to think as teacher, the easiest way to teach culture is to present the factual knowledge. (Matthew/Interview) [emphasis added]

I try to give the smaller insights. Little things like, oh, you know, that the bathroom may not be toilet bath and sink and everything, it might be just a toilet you know, things like that. It's more the day-to-day things, because I think the students are more interested in like differences and ways of life...

(Linda/Interview) [emphasis added]

Joseph very clearly emphasizes in his classroom the historicizing of culture, which tends to be very factual and dependent on dates and reflects his own interests. Although Joseph was one of the participants that opted for the definition "Encourage an open-mind and a positive attitude towards foreign languages and culture" of culture teaching, when it actually comes to teaching in the classroom, Joseph falls into deploying historical facts, which might be due to him feeling more comfortable with the history of the $20^{\text {th }}$ century Germany. $\mathrm{He}$ is a good example of how understanding a complex subject does not necessarily lend itself to practical application for many beginning teachers. In the observations of his teaching, the emphasis on $20^{\text {th }}$ century historical facts and descriptions was evident. He did not combine his discussion of these facts with any language learning nor did he allow for students to mediate culturality. His students were merely receiving the information and not interacting with it. Matthew, just like Joseph, acknowledges to teaching culture in a very factual way. His reasoning highlights the lack of time, which reflects similar findings in other studies (e.g. Omaggio-Hadley, 200I; Sercu et al., 2005). Linda tends to teach factual knowledge as well, especially the "day-to-day" facts, however, in the interview she goes on to say that these day-to-day information "opens them up and gives them a broader perspective... That makes them see that even though other people do things differently, it's not necessarily bad, it's just a different way." This insight by Linda shows that she seems to be the one participant who is trying to think outside of just factual knowledge. Her thoughts on culture teaching seem to include ACTFL's third strand perspectives and IC development, increasing learners' ability to see other cultures from different angles and points of view. Observing Linda yielded surprising results. Two out of the three observations did not include any cultural learning, whether they were facts or mediated cultural learning. In the one observation, she incorporated "culture" by informing her students of the transportation system in Germany and how it functions there. Unfortunately, she did not use this moment to allow students to delve into the learning, but rather left it as information and moved on to practicing vocabulary related to transportation.

While almost $40 \%$ of the participants emphasized historical or knowledge-based facts, three GSls described their culture teaching in terms of using media:

Well, I bring in lots of, uhm, different forms of media, uh, I like to use the Internet and pictures that I have from my own personal experiences [...] How do I teach it? [...] I bring in other cultural artifacts, so not just media, but l'll bring in CDs, of course that's media.

(Justin/Interview) [emphasis added]

Well, for like music for example and videos are really good I think, because they have visual images [...]

(Vanessa/Interview) [emphasis added]

I do emphasize stereotypes not in the way that I strengthen them, but that I try to make clear that there are stereotypes, but they don't have to be the way that people say they are [...] what was the question again?

How do I teach it... and uhm, I guess I use authentic material, like music or videos, like even like the news...

(Ingrid/Interview) [emphasis added]

Both Justin and Vanessa include media, specifically music and videos, in their teaching. It seemed more difficult for Justin to describe what he uses for culture teaching. Having to pause a few times, realizing that $C D s$ are media to finally mentioning other material that he uses in his classroom. While he attempts to list material he uses to teach culture, Justin does not truly describe how he teaches. In fact, none of the participants actually discuss how exactly they teach culture. Vanessa comes the closest by listing videos and music as a big contribution to teaching culture and explains some activities that use the comparison strategy. She elaborates on this aspect in her first self-reflective journal entry when she describes her culture teaching as "Using those materials and having students compare it to their own culture is also beneficial. Introducing culture this way students usually can pick up on differences or similarities between the cultures on their own." Looking at comparisons seems to be a very important part to Vanessa, which reflects one of ACTFL's 5 C's. Looking at differences and similarities is usually a very common approach to culture in FL courses; moving beyond these distinctions or resemblances is the more problematic task for FL instructors (e.g. Sercu et al., 2005).

Although Ingrid eventually discusses her teaching of culture in terms of using media/technology, she begins recounting what she believes she does in her classroom, but soon after stumbles and has to clarify what the question is. Having to do so might explain the difficulty she is having not only with the question, but also with the actual task of teaching culture. After repeating the question to her, she describes using music and videos, but her answer to the question is very brief. Interestingly enough, in her first self-reflective journal entry (as seen above), Ingrid discusses feeling "most comfortable" in teaching culture. This contrasts with not being able to describe how to teach culture and reflects her self-perception and the difficulty that many FL instructors experience when teaching culture. Both Paul and Franc, similar to Ingrid, reveal vagueness and insecurity when it comes to what they actually teach in their classroom in regards to culture. Paul seemed to be unsure about how he teaches culture. He generally did not offer much information. His response on the first self-reflective journal regarding his comfort of teaching culture reads "Culture is somewhat difficult because most of my knowledge of German culture comes from what l've learned in classrooms - and a good portion of that pre-1945. Most students in the first four semesters have very limited interest in anything but contemporary Germany." In his perception of culture teaching, he seems very insecure due to the fact that he feels that the knowledge he has of "German" culture is what he learned in his own classes. This insecurity could lead to uncertainty in implementing cultural learning in his teaching and as observed in all three instances there were no cultural incidents, whether factual or otherwise, in his practices. His teaching concentrated solely on grammatical learning and vocabulary. Franc proves to be even less conversant on how to teach culture. Throughout the interview he stays very vague and poses more questions than responses:

Well, can you teach culture? [...] If you really want to learn about the culture, then buy yourself a plane ticket and fly over there and spend a year two years in the culture and you will learn much more than you are able to conveying it in the classroom. [...] It's part of your lesson and sometimes it's easier to incorporate it and sometimes there 
may not be a chance, I mean if you're talking about grammar, I don't know what chance comes up with for talking culture.

(Franc/Interview) [emphasis added]

In his first self-reflective journal entry, he reflects on his preference of teaching grammar, but also states "However, teaching grammar is not the most satisfying. Teaching culture, for example, gives me the opportunity to show my students aspects of a culture that are not necessarily included in the textbook and differ from place to place." Yet, in his classroom observations, culture was very limited if existing at all. Franc mentioned once a cultural fact about Switzerland and moved on quickly with his lesson on the passive voice. It felt almost as if it was a little side note and was not problematized or incorporated with his lesson, thus not allowing the students to engage with it. Wanting to include culture in their lessons is a common statement by many FL instructors; the application is usually the problem (see Byram \& Kramsch, 2008; Omaggio-Haddley, 200 I; Sercu et al., 2005).

\section{What is ICC/IC?}

When the participants were struggling with the definitions and concepts of culture teaching, the question arises of whether or not they know anything about ICC/IC. Being asked in the interview what ICC is, some instructors just tried taking a guess, or tried explaining the actual words:

Intercultural communicative? But not cultural? So, basically just that in praxis it would result in, if you're interculturally communicatively competent ... there we go, then it would mean that when you're interacting within a different culture, if you don't have the misunderstandings that are caused by intercultural differences?

(Linda/Interview) [emphasis added]

Reflecting on those differences, and, well, difference itself is something, I mean obviously they are finding difference based on what they know. So that would be the intercultural part. I guess, "the inter" refers to this third space that every that language students can occupy between their home culture and the foreign culture. [...] Communicative, uhm, yeah, I feel like the only way I can understand this is by breaking it down. Communicative, I think is just that's the medium. [...] So, and then competence, [...] yeah that's the goal, it's training them... (Matthew/Interview) [emphasis added]

Linda's and Matthew's responses to "what is ICC?" illustrate their unfamiliarity with the term and its meaning. Nevertheless, they attempt dissecting and understanding the term. Other participants elaborated on what they believe the term might mean:

What is intercultural communicative competence? \{whispers it again\} Well, students have their own culture and their own background and you have the target culture, so they kind of know about both to bridge the gap between both of them, [...] they can handle, I guess, I don't know if that is the right word but, what's going on and understand and be more open-minded than others. (Vanessa/Interview) [emphasis added]

ICC, I would say, it's the [pause] our task is to foster the ability for students, or for the students to be conversant in intercultural exchanges and so, it's the ability to take actively part in an intercultural exchange.

(Joseph/Interview) [emphasis added]

I have an idea of what that is. Ok, uhm, it's the ability to navigate, uhm, and use information from one's own cultural context apply it to another cultural context as well as already learned information about the new target culture and be able to make a decision and be able to communicate with other people from that target culture.

(Justin/Interview) [emphasis added]

I think I know. Uhm, to me it means, uhm, how can I phrase this, uhm, l'd say, it's really situational awareness, it's knowing when it's appropriate to say something and when it's not appropriate and or even just recognizing that there is a difference [...] So, an awareness of difference?

(Paul/Interview) [emphasis added]

In the individual interviews with the participants, it becomes apparent that five of them were able to elaborate a little more on the concept of ICC than the others, although it was still not an easy task for any of them. Vanessa, for example, has to whisper the word and think about it for a second before being able to make sense of it. Others begin their answer to the question with either "I have an idea" or "I think I know", which shows the uncertainty of the utterance. Thinking about it for a while and talking themselves through the actual words, the participants in this study attempt to understand this concept through the literal deciphering of the words, their knowledge of teaching languages and cultures, and their own studies. The complexity of IC as a concept is undeniable, and not just for these instructors. The literature provides us with a variety of definitions and theories, which leads to the problem of us expecting FL GSls or FL teachers to know what IC is and how to include IC in their teaching. Many GSIs are not "taught" or trained in terms of IC; they are not familiar with the theories or definitions and the lack of knowledge about the term combined with the lack of training leads to GSIs not mediating interculturality. Additionally, definitions alone do not offer actual implementation into the classroom; rather, definitions are left for interpretation. How beginner teachers are able to interpret these definitions and transform them into classroom actions is still a question to be examined further. Kohler (2015) has started the conversation by looking at teachers and how they mediate intercultural learning; however, more research needs to be done in that area that also leads to more concrete trainings for teachers at all levels.

\section{What strategies/trainings exist for GSIs in terms of culture and IC?}

The challenge to actually "teach" culture and IC is not unique to the participants of this study. As mentioned before, Sercu et al. (2005) show that even though the teachers might know that it is important to include culture and IC in the classroom, they do not feel competent enough to do so. This might be due to lack of learned approaches and strategies to teaching culture and IC and lack of specific training. In this report, the GSls raised the issue of not having or fully understanding approaches to culture teaching.

I think in an ideal situation there would be more time to teach culture, but with a limited number of contact hours per semester in which to cover the amount of grammar etc. that we are expected to cover it's not really feasible.

(Paul/Questionnaire II) 
I think that I think what we do lack though, is specific methodologies as how to teach that other than just the communicative approach. [...] I think there is support for cultural teaching. I don't think that it's explicitly taught so much outside of the 398T course [methods course] and there it's only touched upon for a chapter.

(Justin/Interview) [emphasis added]

It's [culture] hardly ever taught or talked about in the training or mentoring sessions. There was always a lot of talk about the other aspects of language, like grammar, but culture, no, not really. [...] I would like to have some more examples and just some guidance on how to do it and other opinions and insights that would be nice. (Vanessa/Interview) [emphasis added]

It would be much easier if there was an accessible reference source. [...] I don't think that we have a "good" balance, because I don't think we have a good enough methodology for teaching culture. (Linda/Questionnaire III) [emphasis added]

Ok, there probably has not been much instruction, actively, for us. I think, it's probably one of these things, where everybody has to paint for themselves. It's something also among the graduate community we don't really exchange much information like how we do it, which is partly due to the fact that we're all quite busy. I think, yeah, there could be something done there, I think, there should be. (Joseph/Interview) [emphasis added]

Paul, Justin and Vanessa hint at the lack of time to bring culture into the classroom. Byram and Kramsch (2008), OmaggioHadley (200I), and Sercu et al. (2005) report the same finding with their subjects. In addition, not feeling guided enough (Vanessa's case), or not having been taught explicitly, as in Justin's case, leads to the frustration that the GSls experienced and explains their inability to describe how they teach culture. Other GSls wish for a concrete methodology, a reference source, or more instruction as in Linda and Joseph's cases. The GSls receive training on culture in the methods course and they engage with this topic in that class; however, they seem to desire more discussion on this topic, more training, and more concrete strategies and examples. This might be due to the fact that this course is offered in their very first semester and some of the GSls have been teaching for a few years now, so they have not been actively participating in the discourse since then. Ongoing training and regular exchange, as well as discussion on various topics in FL education are needed for teachers to continue to develop professionally and to be able to incorporate standards in their teaching. Some participants recognize this notion.

[...] a workshop on a particular subject in culture would be great.

(Linda/Interview) [emphasis added]

...workshops would be nice, like since culture is such a big term in itself and it connects so many different fields also, uhm, it would maybe be nice to have like a discussion group on those things, but not necessarily a class, whatsoever...

(Ingrid/Interview) [emphasis added]

But I think we need to know more about it as instructors in terms of: "here is a little workshop or something like that."
(Franc/Interview) [emphasis added]

I think workshops would probably be the best way to go about it. I think definitely workshops might have some more of the recent trends on applied linguistics studies but also on pedagogical and methodological approaches...

(Justin/Interview) [emphasis added]

The participants in this study need workshops, in which they could discuss and learn about different approaches to teaching. The importance of professional development for teachers on all levels needs to be stressed, especially our beginning teachers who are not necessarily studying pedagogy as their major, as in the case of GSls. The exchange of this sort of information, even at a very informal level, can aid instructors in their teaching, as it became evident in this study when participants were deciding on what culture meant to them. There thoughts on culture changed throughout the semester (see discussion above) due to having to engage with this topic for this study. The importance of constant and continuous engagement and interaction with the topic is also reflected in the participants comments in the interviews as well as at the end of the focus-group interview.

Justin: Talking about these issues and what we are doing was really helpful. I wonder why we don't do this more.

Franc: I totally agree.

(Focus group interview)

I think through the awareness, yeah, from the talks that we had, you know, on the reflections and from the group discussion, I thought the group discussion was really, really very helpful, in kind of...you know, sometimes you know these things, or you think you know them, but then hearing them again is always, always very, very helpful. (Matthew/Interview) [emphasis added] I think we always need open dialogue. Otherwise nothing's ever going to happen. (Vanessa/Interview) [emphasis added]

\section{CONCLUSION}

The challenge of incorporating culture and IC into our FL courses is evident in many studies (e.g. Kohler, 20I5; Sercu et al., 2005). The topic of culture and IC in the classroom is very complex, starting with the definitions of what our future generations should know. The participants of this study struggled with defining the terms of culture and IC and describing how to teach culture; however, all GSIs strongly believed it is important to incorporate culture in FL instruction. Other studies, such as Sercu et al. (2005), illustrate the awareness that teachers have of culture and IC, yet they do not feel prepared to teach it. The GSls in this study exemplified similar attitudes; they had an understanding of culture belonging in FL pedagogy, but did not feel well prepared to incorporate it in their teaching.

In contradiction to Sercu et al.'s (2005) investigation, the participants in this report where not as familiar with IC as they were with cultural awareness and the factual knowledge of culture. Although they were able to guess the literal meaning of the term, they were not aware of the concept or its full meaning and how to include it in their classroom. Also, feeling uncomfortable and unprepared to teach culture seemed to be due to the lack of training as in Sercu et al.'s (2005) study. Other than lack of training and definition issues that can be seen in the literature thus far, this study illuminated other factors that played a role for the instructors. The curriculum and objectives given to the GSIs as well as what level of 
class they were teaching influenced the way they see culture teaching.

The current qualitative study allowed insights into GSIs' perception of their understanding of teaching culture and IC, the influence this understanding had on their teaching practices, and outlined the training program that they need. Continuous discussions, reflection on their teaching, and the ability to express their struggle with this topic demonstrated the participants' growth, appreciation, and better comprehension of the matter. This progress implies that ongoing professional development throughout this one semester has aided these instructors and thus the inclusion of such is necessary and significant beyond one semester. The demands for workshops and the feeling of not having enough training in the matter indicate the need for developing more hands-on training for GSIs. Developing these workshops should be a priority for programs that train and employ GSIs. This study has also shed light on the IC context in $\mathrm{FL}$ education. The research demonstrates the significance of IC, yet specific approaches to the teaching of IC are still lacking. These approaches might not necessarily exist yet, due to the complexity of IC. However, as can be seen in this study, beginner teachers will need some guidance and examples to follow. Collaboration amongst different teacher education programs and FL programs to develop ongoing, continuous pedagogical training, specifically for teaching IC is necessary. This training could include for example how to deconstruct cultural stereotypes, raise cultural awareness, emphasize learners' own culture and identity, create role-play and situations reflecting intercultural interaction, among others. This way we can ensure the professional development of our GSIs, the inclusion of IC in the FL classrooms and the development of our students' IC.

\section{REFERENCES}

Abrams, Zs. I. (2002). Surfing to cross-cultural awareness: Using Internet-mediated projects to explore cultural stereotypes. Foreign Language Annals, 35(2), I4I-I53.

Agar, M. (1994). Language shock: Understanding the culture of conversation. New York: William Morrow.

Aguilar, M. J. (2007). Dealing with Intercultural Communicative Competence in the foreign language classroom. In E. A. Alcôn Soler \& M. P. Safont Jordà (Eds.), Intercultural language use and language learning. Dordrecht, The Netherlands: Springer.

American Council for the Teaching of Foreign Languages. (1999). Standards for foreign language learning in the 2 Ist century. Yonkers, NY: Allen Press Inc.

Belz, J. A. (2002). Social dimensions of telecollaborative language study. Language Learning and Technology 6(I), 60-8I.

Belz, J. A. (2005). Intercultural questioning, discovery and tension in internet-mediated language learning partnerships. Language and Intercultural Communication, 5(1), 3-39.

Byram, M. (1986). Minority education and ethnic survival. Case study of a German school in Denmark. Clevedon, Avon, England: Multilingual Matters Ltd.

Byram, M. (1997). Teaching and assessing intercultural communicative competence. Philadelphia: Multilingual Matters Ltd.

Byram, K., \& Kramsch, C. (2008). Why is it so difficult to teach language as culture? The German Quarterly, 8I(I), 20-34.

Chavez, M. (2002). We say "culture" and students ask "What?": University students' definitions of foreign language culture. Die Unterrichtspraxis/Teaching German, 35(2), I29-I40.

Chavez, M. (2005). Variation in the beliefs of college students of German about the teaching of culture. Die Unterrichtspraxis/Teaching German, 38(I), 3I-43.

Cushner, K., \& Mahon, J. (2009). Intercultural competence in teacher education - Developing the intercultural competence of educators and their students. In D. K.
Deardorff (Ed.), The Sage Handbook of Intercultural Competence (pp. 304-320). Los Angeles: Sage.

Deardorff, D. K. (2009). Synthesizing conceptualizations of Intercultural Competence: A summary and emerging themes. In D. K. Deardorff (Ed.), The Sage Handbook of Intercultural Competence (pp. 264-270). Los Angeles: Sage.

Doğançay-Aktuna, S. (2005). Intercultural communication in English language teacher education. ELT, 59(2), 99-I07.

Ghanem, C. (20I4). "Intercultural Communicative Competence: Have TAs Heard of Such a Thing?" In B. Dupuy \& L. Waugh (Eds.), Selected Proceedings of the Fourth International Conference on the Development and Assessment of Intercultural Competence, 3, 78-93.

Glaser, B.G. (1992). Basics of grounded theory analysis. Mill Valley, CA: Sociological Press.

Hall, E. T. (1990). Understanding cultural differences. Yarmouth, Maine: Intercultural Press.

Kohler, M. (2015). Teachers as mediators in the foreign language classroom. Tonawanda, NY: Multilingual Matters.

Kramsch, C. (1998). Language and culture. Oxford: Oxford University Press.

Kramsch, C. (2000). Context and culture in language teaching. Oxford: Oxford University Press.

Liddicoat, A.J. (2002). Static and dynamic views of culture and intercultural language acquisition. Babel, 36(3), 4-II.

Liddicoat, A.J., Papademetre, L., Scarino, A. \& Kohler, M. (2003). Report on intercultural language learning. Canberra: Department of Education, Science and Training. Australian Government.

Merriam, S. (2009). Qualitative research: A guide to design and implementation. San Francisco, CA: Jossey-Bass.

Omaggio-Hadley, A. (200I). Teaching language in context. Boston, MA: Heinle \& Heinle.

Sercu, L. (2006). The foreign language and intercultural competence teacher: The acquisition of a new professional identity. Intercultural Education, I 7(I), 55-72.

Sercu, L., Bandura, E., Castro, P., Davcheva, L., Laskaridou, C., Lundgren, U., Del Carmen Méndez García, M., \& Ryan, P. (2005). Foreign language teachers and intercultural competence: An international investigation. Buffalo: Multilingual Matters Ltd.

The MLA Ad Hoc Committee. (2007). Foreign languages in higher education: New structures for a changed world. Retrieved from http://www.mla.org/flreport.

Ware, P. D. (2005). "Missed" communication in online communication: Tensions in a German-American telecollaboration. Language Learning and Technology, 9(2), 64-89. 


\section{APPENDIX A}

Figure 2. Questionnaire item on "culture teaching"

2. What is "culture teaching" in your opinion? Please rate the following statements on a scale from I-5, with I being the most important and 5 least important.

Students learn about history, geography, and politics of the foreign culture.

Students learn about daily life.

Students learn about value and beliefs of Germans.

Encourage an open-mind and appositive attitude towards foreign languages and cultures.

Handling intercultural situations.

Any comments on culture teaching:

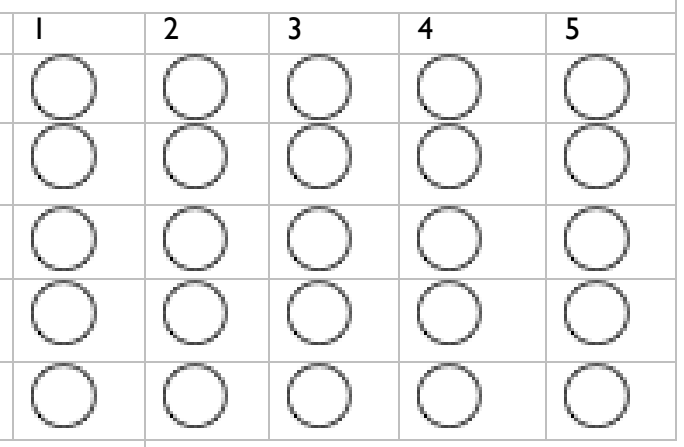

